\title{
Tingkat Konsumsi Ikan di Indonesia: Ironi di Negeri Bahari
}

[Level of fish consumption in Indonesia: irony in the nautical country]

\author{
Iin Siti Djunaidah ${ }^{\bigotimes}$ \\ Jurusan Penyuluhan Perikanan - Sekolah Tinggi Perikanan \\ Jalan Cikaret Nomor 2 Bogor, Jawa Barat
}

Diterima : 15 Juni 2017 : Disetujui : 22 Juli 2017

\begin{abstract}
Abstrak
Ikan sebagai bahan pangan di Indonesia memiliki beberapa keunggulan, diantaranya: sebagai sumber nutrisi esensial, white meat, bersifat universal, harga relatif murah, proses produksi relatif singkat, serta suppy lokal. Tingkat konsumsi ikan di Indonesia relatif rendah dibandingkan dengan potensi sumber daya perikanan yang dimiliki. Angka konsumsi ikan pada tahun 2010 sebesar 30,48 kg/kap/th, meningkat setiap tahunnya hingga mencapai $38,1 \mathrm{~kg} / \mathrm{kap} / \mathrm{th}$ pada tahun 2014 dengan tingkat pertumbuhan sebesar 5,78\%. Penyediaan ikan pada tahun 2010 sebesar 38,39 $\mathrm{kg} / \mathrm{kap} / \mathrm{th}$ dan meningkat menjadi $51,8 \mathrm{~kg} / \mathrm{kap} / \mathrm{th}$ pada tahun 2014 dengan tingkat pertumbuhan sebesar 7,85\%. Penyebab rendahnya konsumsi ikan diantaranya adalah kurangnya pemahamn masyarakat tentang manfaat mengkonsumsi ikan, kurang lancarnya distribusi ikan, belum optimalnya sarana dan prasarana serta mitos yang berkembang di masyarakat. Regulasi perikanan diantaranya UU No 31 thn 2004 tentang Perikan jo UU No 45 th 2009 , UU No 18 tahun 2012 tentang Pangan serta INPRES No. 1 tahun 2017 tentang Gerakan Masyarakat Hidup Sehat.
\end{abstract}

Kata kunci: keunggulan ikan, konsumsi ikan, regulasi perikanan

\begin{abstract}
Fish as food in Indonesia has several advantages, including: as a source of essential nutrients, white meat, universal, relatively cheap price, relatively short production process, and local suppy. The level of fish consumption in Indonesia is relatively low compared to the potential of fishery resources. Figures for fish consumption in 2010 amounted to $30.48 \mathrm{~kg} / \mathrm{cap} /$ year, increasing every year to reach $38.1 \mathrm{~kg} / \mathrm{kap} /$ th in 2014 with a growth rate of $5.78 \%$. The provision of fish in 2010 amounted to $38.39 \mathrm{~kg} / \mathrm{cap} /$ th and increased to $51.8 \mathrm{~kg} / \mathrm{kap} /$ th in 2014 with a growth rate of $7.85 \%$. The causes of low consumption of fish include lack of understanding of the benefits of consuming fish, lack of smooth distribution of fish, not optimal facilities and infrastructure and myths that developed in the community. Regulation of fisheries such as Law No 31 of 2004 on Perikanan jo UU No 45 th 2009, Law No. 18 of 2012 on Food and President Instruction No. 1 of 2017 on Healthy Life Society Movement.
\end{abstract}

Key words : fish consumption, fish advantages, regulation of fisheries

$\triangle$ Penulis korespondensi

Alamat surel: iin.djunaidah@gmail.com 


\section{PENDAHULUAN}

Sebagai negara bahari dan kepulauan terbesar di dunia, Indonesia memiliki berbagai macam ekosistem pesisir dan laut diantaranya sumberdaya perikanan. Meskipun potensi dan pemanfaatan sumberdaya perikanan di perairan tawar, payau maupun laut relatif tinggi, akan tetapi makan ikan belum menjadi budaya di sebagian besar wilayah Indonesia. Faktanya, tingkatan konsumsi ikan masyarakat Indonesia tertinggal jauh di bawah bangsa-bangsa lain yang memiliki potensi sumberdaya perikanan jauh lebih kecil. Negara Jepang yang total luas wilayahnya sekitar $85 \%$ dari pulau Sumatera, dengan garis pantai sepanjang $29.751 \mathrm{~km}$ serta luas lautan $3.091 \mathrm{~km}$ persegi, dan dengan tingkat konsumsi ikan kg per-kapita per-tahun mencapai angka $140 \mathrm{~kg}$ per-kapita per-tahun. Begitu pula dengan negara tetangga lain seperti Malaysia dan Korea Selatan yang masingmasing memiliki panjang garis pantai 6475 $\mathrm{km}$ persegi dan $2413 \mathrm{~km}$ persegi memiliki tingkat konsumsi ikan masing-masing sebesar 70, serta $80 \mathrm{~kg}$ per-kapita pertahun (Setyorini, 2007)

Bangsa di Asia yang mengkonsumsi ikan lebih banyak daripada bangsa-bangsa lain mempunyai tingkat etos kerja yang mengagumkan sebagaimana ditunjukkan oleh Jepang dan Korea Selatan yang selalu menunjukkan inovasinya dalam berbagai bidang. Bangsa Jepang adalah salah satu contoh masyarakat yang kultur pangannya sangat diwarnai pangan dari laut. Sejak abad ke tujuh, masyarakat Jepang telah mengembangkan dan mengkonsumsi luas produk olahan ikan berbasis surimi. Pangan dari laut begitu terintegrasi ke dalam kultur pangan bangsa Jepang (Setyorini, 2006). Hal ini berbeda dengan kondisi di Indonesia, sumber pangan dari perairan laut belum dikenal dan dikonsumsi secara luas dan merata di seluruh Indonesia. Bahkan untuk di sebagian besar wilayah pulau Jawa sebutan ikan digandengkan dengan sumber pangan protein lainnya. Sangat lazim diucapkan, iwak tahu, iwak tempe, iwak ayam sehingga muncul kesan seolah-olah peran ikan tersamarkan. Hasil penelitian Ilham dkk (2002) mengindikasikan bahwa ikan merupakan produk substitusi daging sapi, kambing/domba dan babi.

Dengan beberapa keunggulan komparatif maupun kompetitif yang dimiliki ikan sebagai bahan pangan sumber protein hewani, dibarengi dengan intervensi pemerintah serta pihak terkait lainnya maka pengingkatan angka konsumsi ikan masyarakat Indonesia berpeluang dapat tercapai. Upaya peningkatan konsumsi ikan akan memberikan multiflier effect, selain meningkatkan tingkat kesehatan serta 
kecerdasan masyarakat, juga makin menggairahkan sektor perikanan yang pada pada gilirannya dapat mendorong peningkatan penyerapan tenaga kerja, meningkatkan nilai pendapatan serta kesejahteraan suatu masyarakat dan memposisikan kondisi profesi nelayan, pembudidaya ikan, pengolah hasil kelautan dan perikanan serta pihak terkait lainnya sebagai pilihan favorit.

Tujuan kajian ini adalah untuk (1) Menganalisis keunggulan ikan sebagai bahan pangan; (2) Menganalisis konsumi ikan di Indonesia; (3) Menganalisis penyebab relatif rendahnya konsumi ikan di Indonesia; dan (4) Menganalisis aspek regulasi.

\section{BAHAN DAN METODE}

Dalam kajian ini digunakan analisis deskriptif yang didasarkan pada telaahan studi pustaka dengan menggunakan data sekunder sebagai sumber informasi.

\section{Keunggulan ikan sebagai bahan pangan}

Sebagai salah satu sumber protein hewani bagi pemenuhan kebutuhan masyarakat Indonesia, ikan memiliki berbagai keunggulan.

Sumber nutrisi esensial. Sebagai bahan pangan, Ikan tidak hanya sebagai sumber protein, ikan juga sebagai sumber lemak, vitamin, dan mineral yang sangat baik dan prospektif. Data Susenas BPS menunjukkan bahwa sumbangan protein ikan terhadap konsumsi protein hewani masyarakat Indonesia mencapai $57 \%$ (Saefudin, 2015). Kelebihan ikan sebagai salah satu sumber protein hewani adalah karena kuantitasnya yang mengandung protein dalam kisaran $15-24 \%$ serta kualitasnya yang ditunjukkan dengan kelengkapan asam amino esensialnya serta tingkat kecernaaanya yang mencapai angka 95\% (Rahayu dkk., 1992). Selain itu, ikan juga mengandung asam lemak omega-3 yang sangat penting bagi perkembangan jaringan otak dan mencegah terjadinya penyakit jantung, stroke dan darah tinggi serta mengurangi resiko beberapa jenis penyakit lainnya. Begitu pula peneliti lain, Leaf dan Weber (1988) melaporkan bahwa mengkonsumsi ikan mampu melindungi dari serangan penyakit jantung diduga karena faktor keberadan asam lemak omega 3 dalam ikan. Asam lemak tersebut memiliki peran penting dalam metabolism seperti menghambat platelet aggregation dan menurunkan level dari serum triglyceride yang akan memegang peranan dalam pencegahan penyakit jantung. Peneliti sebelumnya, Kremhout et.al (1985) juga mengindikasikan adanya perbandingan terbalik antara jumlah konsumsi ikan dengan kejadian kematian karena serangan jantung. Heruwati (2002) menyatakan bahwa ikan diakui sebagai fungsional food 
yang memiliki arti penting bagi kesehatan karena mengandung asam lemak tidak jenuh berantai panjang (terutama yang tergolong asam lemak omega 3). Dari hasil penelitiannya terhadap tiga kelompok sampel yang berkebangsaan Finlandia, Italia dan Belanda, Oomen $d k k$ (2005) melaporkan bahwa terdapat hubungan antara konsumsi ikan dengan kematian akibat serangan jantung. Mereka juga menyatakan bahwa asam lemak omega 3 yang ada terkandung dalam ikan yang dikonsumsi berperan secara nyata.

Sebagaimana disampaikan oleh Elvira Syamsir dari IPB, alasan mengapa ikan dikatakan lebih menyehatkan ketimbang protei hewani lain, sebagai berikut: mengandung protein yang bermutu tinggi dan rendah kandungn lemak jenuh, kadar protein kasar 16-27 per 100 gram. Mengandung asam lemak Omega 3, 6 dan 9 yang sangat tinggi, sumber vitamin dan mineral yang sangat tinggi, mengandung asam amino esensial, lemak rendah dari pada ayam. Selanjutnya disampaikan bahwa ada yang khas dalam kepiting, kerang dan tiram. Pada kelompok komoditas ini terdapat zat taurin yang berfungsi sebagai perkembangan sel syaraf bayi melalui air susu ibu yang dikenal dengan sebutan ASI (Anonim, 2013).

Bagi ibu-ibu hamil, ikan dipercaya mampu membantu pertumbuhan otak janin secara pesat pada minggu ke-20 hingga minggu ke-36 sebagaimana disampaikan oleh Kepala Badan Litbang Kesehatan, Prof dr Tjandra Yoga Aditama (Rafikasari, 2015). Sebagai gambaran kandungan omega 3 pada ikan melebihi hewan ternak lainnya. Pada setiap $100 \mathrm{~g}$ ikan dalam hal ini kelompok ikan bersirip (finfish) mengandung $210 \mathrm{mg}$, tiram $150 \mathrm{mg}$, udang 200mg, lobster $105 \mathrm{mg}$. Angka ini jauh melampaui kandungan omega-3 pada hewan ternak seperti sapi, ayam, serta kambing yang masing-masing memiliki kandungan omega-3 sebesar $22 \mathrm{mg}, 19 \mathrm{mg}$ serta $18 \mathrm{mg}$ pada setiap $100 \mathrm{~g}$ daging hewan ternak tersebut. Hasil penelitian lain menyimpulkan bahwa siswa-siswa yang mengkonsumsi ikan dengan frekuensi dan kecukupan asam lemak tidak jenuh pada ikan, EPA dan DHA tinggi menunjukkan prestasi belajar siswa baik (Zulaikah \& Widyati, 2004)

Ikan sebagai white meat. Salah satu sumber protein yang baik bagi tubuh manusia adalah daging, yang berdasarkan jenisnya dibedakan antara daging merah dan daging putih. Daging merah berasal dari daging sapi, domba, kambing, kuda, sedangkan daging putih berasal dari hewan unggas, serta ikan. Secara fisik, sebagian besar daging ikan berwarna putih, yang terdapat di hampir semua bagian dari tubuh. Daging warna merah pada ikan 
hanyalah bagian kecil saja, biasanya hanya terdapat di bagian samping dari tubuh ikan di bawah kulit. Daging ikan yang berwarna putih memiliki kadar protein lebih tinggi dan kadar lemak yang lebih rendah dibandingkan dengan bagian daging berwarna merah (Rahayu, dkk., 1992). Kesadaran masyarakat global mengkonsumsi ikan adalah karena alasan kesehatan. Mereka akan lebih memilih mengkonsumsi daging putih seperti ikan ketimbang daging merah. Itulah sebabnya mengapa ikan Dorry (sebutan untuk filet ikan asal Vietnam) sangat disukai oleh konsumen di luar negeri karena dagingnya yang berwarna putih.

Ikan bersifat universal. Sebagai bahan pangan, ikan dapat diterima oleh semua agama dan semua golongan di Indonesia. Boleh dikatakan, tidak ada pantangan makan ikan dari komunitas yang ada di wilayah Indonesia. Selain itu ikan dapat dikonsumsi manusia dalam hampir di semua umur, kecuali bayi yang pola makannya masih menggantungkan air susu ibu (ASI) .

Harga relatif murah. Dilihat dari sisi harga diantara sumber protein hewani, dapat dikatakan keterjangkauan konsumen terhadap ikan relatif lebih tinggi. Harga ikan tawar seperti ikan Lele, ikan Mas, Nila, Bandeng sekitar Rp 25.000, - sampai Rp 35.000,- per kg. Ikan laut memang memiliki harga lebih tinggi dibandingkan dengan komoditas ikan air tawar. Udang yang berukuran 70 atau sekitar $15 \mathrm{~g}$ per ekor sebagai ukuran yang biasa dikonsumsi masyarakat luas memiliki harga Rp 70.000,- per kg. Harga ikan tawar sepadan dengan harga daging (per ekor Rp 34.000,-) dan telur ayam sekitar Rp 20.000,-/kg. Lain halnya dengan harga daging sapi yang masih bertahan di kisaran Rp 120.000,- $\quad$ sampai $150.000,-/ \mathrm{kg}$, (Anonim, 2016).

Memiliki keragaman jenis. Jenis ikan yang dapat dikonsumsi manusia beraneka ragam, mengingat ikan konsumsi berasal dari berbagai jenis perairan, yakni perairan tawar, payau dan laut. Selain beragam jenisnya, rasa ikanpun beragam terkait dengan asal media hidupnya. Ikan dari laut relatif lebih gurih dibandingkan dengan ikan air tawar. Selain varian rasa, bentuk, serta ukuran, harga ikan sangat bervariasi. Oleh karena itu tersedia banyak pilihan bagi konsumen untuk mengambil sebuah keputusan. Keragaman yang sangat tinggi pada ikan menyebabkan ikan dapat diproses lebih lanjut menjadi berbagai macam olahan, sehingga dapat memenuhi semua segmen kelas ekonomi.

Proses produksi relatif singkat. Lama pemeliharaan komoditas ikan relatif singkat, hanya diperlukan hitungan bulan masa pemeliharaan untuk memperolah 
ikan ukuran konsumsi. Apalagi banyak konsumen yang sangat menggemari ikan berukuran kecil atau dikenal dengan baby fish dari berbvagai jenis ikan seperti ikan Nila dan Mas. Untuk mencapai ukuran tersebut terbilang singkat waktu pemeliharanya. Sekitar satu bulan baby fish dapat dipanen dan dipasarkan. Untuk udang misalnya diperlukan waktu pemeliharaan sekitar 100 hari untuk mencapai ukuran konsumsi, sehinnga dalam satu tahun dapat diproduksi tiga kali. Untuk ikan Gurame memerlukan waktu lebih lama, sekitar delapan bulan apabila dipelihara langsung dari benih. Begitu pula untuk ikan laut seperti ikan Kerapu dan Bawal Bintang misalnya.

\section{Supply lokal (dalam negeri).}

Boleh dikatakan bahwa semua jenis ikan yang biasa dikonsumsi masyarakat Indonesia murni merupakan ikan produk lokal. Bila diamati di beberapa pusat perbelanjaan, tidaklah banyak ragam ikan import yang disajikan, yang paling menonjol dari sisi ikan segar adalah ikan Salmon. Dapat dikatakan bahwa seluruh penyediaan semua kebutuhan ikan konsumsi di pasar domestik dilakukan oleh produsen dalam negeri (lokal). Dengan kata lain, ikan sebagai bahan pangan masyarakat negeri ini tercukupi oleh produk lokal. Hal ini mengindikasikan bahwa sektor perikanan pada kondisi saat ini telah mendekati kategori Kemandirian
Pangan sebagaimana diamanatkan dalam Undang-Undang Nomor 18 tahun 2012 tentang Pangan pasal 1 ayat 3 .

\section{Tingkat konsumsi ikan di indonesia}

Tingkat konsumsi ikan atau sekarang dikenal dengan Angka konsumsi ikan merupakan tingkat konsumsi masyarakat Indonesia terhadap komoditas ikan yang dikonversi dalam satuan kg per-kapita pertahun. Terdapat sebuah hasil penelitian yang cukup menarik terkait konsumsi ikan; yang menyimpulkan bahwa konsumsi ikan suku Bugis lebih tinggi dibandingkan dengan suku Sunda yang keduanya berdomisili di wilayah yang sama yakni sekitar waduk Cirata. Rata-rata kontribusi ikan yang dikonsumsi terhadap angka kecukupan protein suku Bugis adalah 67,9 $\%$ sedangkan untuk suku Sunda 25,8\%. Kontribusi ikan terhadap angka kecukupan energi untuk suku Sunda dan Bugis masing-masing $\quad 7,2 \%$ dan $15,9 \%$. (Suryadiana dkk., 2014). Hal ini mengindikasikan bahwa terdapat adanya perbedaan pola konsumsi atau budaya makan ikan berdasar suku/etnis, mungkin lebih tepatnya geografis asal. Budaya makan ikan sebagai bagian dari budaya bahari lebih melekat pada suku Bugis yang memang dari sejarah terbuktikan bahwa mereka merupakan kelompok pelaut ulung. Angka Penyediaan ikan dan Konsumsi ikan dari tahun ke tahun 
menunjukkan peningkatan (Tabel 1). Rata-rata peningkatan penyediaan ikan dalam kurun waktu lima tahun yakni pada periode 2010 sampai dengan 2014 sebesar7,85\%, sedangkan kenaikan dalam jangka waktu satu tahun yakni pada periode 2013 sampai dengan 2014 sebesar $8,44 \%$. Rata-rata peningkatan Angka konsumsi ikan dalam kurun waktu 5 tahun yakni dari tahun 2010 sampai dengan 2014 sebesar 5,78 \%, sedangkan kenaikan angka konsumsi ikan dalam setahun yakni 20132014 sebesar 8,32\%. Capaian angka (sementara) konsumsi ikan pada tahun 2015 adalah sebesar $41,11 \mathrm{~kg}$ per-kapita per-tahun, sedikit melebihi target yang telah ditetapkan. Mencermati Tabel 1, angka penyediaan ikan selalu melebihi angka konsumsi ikan.

Dalam upaya mensinkronkan antara penyediaan ikan dengan angka kebutuhan untuk konsumsi perlu direncanakan secara matang, agar ada jaminan bahwa ikan selalu tersedia sesuai kebutuhan sehingga tidak perlu terjadi kekurangan supply (penyediaan). Diperlukan perhitungan lebih detail per wilayah baik untuk perkiraan angka penyediaan maupun angka konsumsi. Berdasarkan Anonim (2017) paparan Kinerja 2016 \& Outlook 2017 Ditjen PDS, terlihat bahwa ada target kenaikan angka konsumsi ikan pada setiap tahunnya. Pada tahun 2016 angka konsumsi Pada tahun 2016 angka konsumsi ikan diharapkan meningkat menjadi 43,88 kg/kap/th. Selanjutnya pada tahun 2017, 2018, 2019 serta 2020 diharapkan angka konsumsi ikan masingmasing menjadi 47,12 kg/kap/th; 50,65 $\mathrm{kg} / \mathrm{kap} / \mathrm{th} ; \quad 54,49 \mathrm{~kg} / \mathrm{kap} / \mathrm{th}$ serta 54,49 $\mathrm{kg} / \mathrm{kap} / \mathrm{th}$ pada tahun 2020. Bila demikian halnya, maka perlu ada strategi peningkatan penyediaan ikan baik yang berasal dari usaha perikanan tangkap maupun perikanan budidaya.

Angka konsumsi ikan sangat bervariasi dari satu wilayah ke wilayah lainnya (Tabel 2). Merujuk pada angka sementara pada tahun 2015, angka konsumsi ikan berkisar antara 20,2 $\mathrm{kg} / \mathrm{kap} /$ th sampai dengan 55,35 kg.kap/th. Terdapat lima Propinsi dengan angka konsumsi ikan di bawah $30 \mathrm{~kg} / \mathrm{kap} / \mathrm{th}$ yakni Propinsi Jawa Barat (26,27 $\mathrm{kg} / \mathrm{kap} / \mathrm{th})$, Jawa Tengah (22,37 kg/kap/th), Jawa Timur $(28,96 \mathrm{~kg} / \mathrm{kap} / \mathrm{th}), \quad$ D.I.

Tabel 1. Angka Penyediaan, Konsumsi ikan serta Pertumbuhannya periode Tahun 2010-2014

\begin{tabular}{lcccccccc}
\hline \multirow{2}{*}{ Uraian } & \multicolumn{9}{c}{ Tahun } & \multicolumn{3}{c}{ Pertumbuhan (\%) } \\
\cline { 2 - 8 } & 2010 & 2011 & 2012 & 2013 & 2014 & 2015 & $2010-2014$ & $2013-2014$ \\
\hline $\begin{array}{l}\text { Penyediaan ikan } \\
\text { (kg.kap.-1.th } \text {. }^{-1} \text { ) }\end{array}$ & 38,39 & 42,49 & 47,22 & 47,77 & 51,80 & & 7,85 & 8,44 \\
$\begin{array}{l}\text { Penyediaan } \\
\text { ikan (kg.kap } \\
\text { 1.th }\end{array}$ & 30,48 & 32,25 & 33,89 & 35,21 & 38,14 & 41,11 & 5,78 & 8,32 \\
\hline
\end{tabular}


Sumber: kkp.go.id. 12 April 2016. Diunduh 19 Mei 2017(Anonim, 2016)

Yogyakarta 23,21 kg/kap/th) serta Lampung (28,66 kg/kap/th). Adapun lima Propinsi dengan angka konsumsi ikan melebihi $50 \mathrm{~kg} / \mathrm{kap} /$ th meliputi Propinsi Maluku (55,35 kg/kap/th), Maluku Utara

Belum ada jawaban pasti, mengapa tingkat konsumsi ikan dalam masyarakat Indonesia masih tergolong relatif rendah dibandingkan dengan negara lain dan dibandingkan dari potensi sumberdayanya. Beberapa hal yang diduga menjadi penyebab masih relatif rendahnya tingkat konsumsi ikan di Indonesia, diantaranya adalah: 1). Kurangnya pemahaman masyarakat tentang gizi dan manfaat ikan bagi kesehatan dan kecerdasan, 2). Rendahnya supply ikan akibat kurang lancarnya distribusi, 3). Belum berkembangnya teknologi pengolahan dan atau pengawetan ikan sebagai bentuk keanekaragaman dalam ikut memenuhi tuntutan selera semua konsumen, 4) sarana pemasaran, distribusi terbatas baik kualitas maupun kuantitas (Anonim, 2014). Hal lain yang diduga menyebabkan masih rendahnya tingkat konsumsi ikan di Indonesia adalah pola fikir masyarakat vano masih kedarat-daratan citra ikan
$(50,75 \mathrm{~kg} / \mathrm{kap} / \mathrm{th}), \quad$ Sulawesi Tenggara (52,60 kg/kap/th), serta Kepulauan Riau $(52,58 \mathrm{~kg} / \mathrm{kap} / \mathrm{th})$.

\section{Penyebab relatif rendahnya konsumsi ikan di indonesia}

sebagai penyebab penyakit cacingan, sumber alergi, ikan meningkatkan kholesterol darah dan kandungan logam berat. Merujuk pada Tabel 2. Secara jelas terlihat bahwa empat provinsi di pulau Jawa menunjukkan angka konsumsi di papan bawah, kurang dari $30 \mathrm{~kg} / \mathrm{kap} / \mathrm{th}$. Adanya penyebutan iwak tempe, iwak tahu, iwak ayam di beberapa daerah di Jawa mengindikasikan bahwa makan ikan belum menjadi budaya.

Terkait dengan pola konsumsi ikan masyarakat Indonesia, telah banyak penelitian yang relevan. Mungkin saja diantara hasil penelitian yang sporadis dilakukan di berbagai wilayah, minimal dapat membantu mengidentifikasi masalah rendahnya konsumsi ikan di Indonesia. Salah satu hasil penelitian menyimpulkan bahwa jumlah konsumsi ikan di sentra produksi lebih tinggi dibandingkan dengan di daerah yang non sentra produksi.

Tabel 2. Angka Konsumsi Ikan pada Tahun 2015 di Beberapa Propinsi

\begin{tabular}{ccc}
\hline No. & Angka konsumsi ikan $(\mathrm{kg} / \mathrm{kap} / \mathrm{th})$ & Jumlah Propinsi \\
\hline 1. & $\leq 30$ & 5 \\
2. & $\leq 40$ & 10 \\
3. & $\leq 50$ & 14 \\
4. & $>50$ & Jurnal Penyuluhan Perikanan dan Kelautan \\
\hline
\end{tabular}


Selain itu pada variabel pendapatan, jumlah tanggungan keluarga, pendidikan dan selera berpengaruh nyata terhadap jumlah konsumsi jenis ikan (Chotimah, 2003). Selanjutnya, Indrawasih (2016) yang melakukan penelitian di Desa Hitumesing, Kabupaten Maluku Tengah menyimpulkan bahwa konsumsi ikan oleh penduduk relatif rendah dibandingkan dengan tingkat produksi yang ada. Nelayan lebih suka menjual ikan hasil tangkapannya ketimbang mengkonsumsinya. Hal ini diduga karena nelayan membutuhkan uang cash untuk membeli kebutuhan primer para nelayan. Mungkin harga ikan jauh lebih mahal dibandingkan dengan bahan pangan lainnya.

Peneliti lain, Sokib, $d k k$ (2012) melaporkan hasil penelitiannya bahwa meningkatnya pendidikan konsumen mengakibatkan pergeseran dari konsumsi ikan segar ke produk olahan. Hal serupa dilaporkan oleh Suryawati, $d k k$ (2016) yang melaporkan bahwa pilihan konsumsi ikan dalam bentuk segar mengalami pergeseran menjadi bentuk olahan seiring dengan akan meningkatnya pendidkan konsumen. Preferensi masyarakat terhadap ikan secara umum menunjukkan pola preferensi yang homogen. Selain itu, preferensi masyarakat terhadap ikan secara umum menunjukkan pola yang Volume 11 Nomor 1 April 2017 homogen. Selanjutnya Indriana dan Widayanti (2006) melaporkan bahwa semakin tinggi pendapatan/kap/bulan dan pengetahuan tentang gizi seorang ibu maka semakin meningkatkan ketersediaan ikan di rumah tangga perkotaan. Hal ini mengindikasikan bahwa sosok ibu sangat mempengaruhi ketersediaan ikan di rumah tangga. Hal ini sejalan dengan hasil penelitian yang dilakukan Rahfiludin $d k k$ (2004) yang mengambil sample ibu rumah tangga yang memiliki anak bawah lima tahun atau balita. Hasil dari penelitian menunjukkan keberadaan peningkatan yang signifikan atas berbagai aspek seperti pengetahuan, keterampilan serta sikap dalam mengkonsumsi ikan dari ibu-ibu sampel yang telah mengikuti pelatihan, Dari hasil penelitian penelitian tersebut, mengindikasikan bahwa edukasi terhadap ibu rumah tangga berdampak positif terhadap kesadaran konsumsi ikan.

\section{Dukungan regulasi}

Di tataran global, 20 tahun silam, para pelaku usaha perikanan dunia mendeklarasikan Hari Perikanan Dunia atau World Fisheries Day (WFD) pada tanggal 21 Nopember 1997 di New Delhi, India. Gagasan munculnya WFD tidak lain sebagai ungkapan rasa keprihatinan dan kekhawatiran melihat 
fakta makin menurunnya produksi perikanan di seluruh dunia. Di sisi lain, terjadinya penambahan populasi manusia di dunia yang diikuti dengan kebutuhan bahan pangan sumber protein hewani.

Indonesia yang memiliki puluhan ribu pulau, garis pantai terpanjang ke dua di dunia serta potensi sumberdaya perikanannya melimpah berhasil memiliki Undang-Undang Nomor 31 tahun 2004 tentang Perikanan. Dalam pelaksanaan Undang-Undang tersebut diwarnai dengan dinamika di lapangan, sehingga lima tahun kemudian telah berhasil juga dilakukan penyempurnaan sehingga muncul Undang-Undang Nomor 45 tahun 2009. Dalam UndangUndang tersebut dijelaskan secara holistik bagi pengaturaan pengelolaan sumberdaya ikan, jenis dan bentuk usaha perikanan, sampai pada penindakan atas pelanggaran yang dilakukan. Hal yang spektakuler diantaranya adalah dimulainya pengadilan Perikanan secara khusus yang bertempat di Pengadilan di beberapa wilayah sentra produksi diantaranya Belawan (Sumatera Utara), Jakarta, Tual (Maluku). Saat itu pula Kementerian Kelautan dan Perikanan bekerja sama dengan pihak Kejaksaan serta Mahkamah Agung bersama-sama merekrut jaksa dan hakim ad hoc perikanan.
Puluhan tahun urusan perikanan menjadi subordinasi dari pertanian walaupun $75 \%$ dari wilayah Indonesia adalah lautan. Sebagai bagian dari pertanian sudah barang tentu kebijakan pemerintah atas pengembangan perikanan tidak optimal. Itu pula mungkin salah satu hal yang menyebabkan rendahnya angka konsumsi ikan masyarakat Indonesia. Gerakan Memasyarakatkan Makan Ikan (Gemarikan) telah dicanangkan pada 4 April 2004 oleh Presiden RI ke-5, ibu Megawati Soekarnoputri; yang antara lain bertujuan untuk membangun kesadaran gizi individu maupun kolektif masyarakar agar gemar mengkonsumsi ikan.

Posisi ikan sebagai bahan pangan menjadi strategis manakala diterbitkan Undang-Undang Nomor 18 tahun 2012 tentang Pangan. Ikan secara eksplisit dicantumkan di dalam Undang-Undang tersebut. Ini merupakan pengakuan formal dari negara atas eksistensi ikan. Pengakuan negara menjadi penting karena berkaitan dengan fasilitasi kebijakan di dalamnya. Hadirnya Undang - Undang Pangan tersebut, posisi ikan sejajar dengan bahan pangan lainnya yang berasal dari sumber hayati produk pertanian, perkebunan, 
kehutanan, dan peternakan sebagaiaman tercantum dalam pasal 1 ayat 1 .

Untuk mengoperasionalkan posisi ikan di masyarakat, perlu ada kebijakan yang terintegrasi antar sektor, antar Kementerian serta para pihak yang terkait. Kebijakan ketahanan pangan bukan melulu sekedar soal produksi dan konsumsi pangan secara kuantitatif, namun juga soal kualitas konsumsi pangan masyarakat. Dalam kerangka ketahanan pangan, konsumsi pangan yang bagus bukan hanya memenuhi kebutuhan dari rasa lapar, namun juga mempunyai dampak pada naiknya kesehatan, kecerdasan dan kualitas hidup masyarakat. Ikan sangat layak untuk dikonsumsi karena memiliki kandungan gizi yang memadai (Kinasih, 2012). Pengakuan negara terhadap ikan diperkuat dengan terbitnya Keputusan Presiden Nomor 3 tahun 2014, yang menetapkan tanggal 21 Nopember sebagai Hari ikan Nasional (HIN). Penetapan tanggal tersebut merujuk pada Hari Perikanan Dunia yang diperingati setiap tanggal 21 Nopember. Dengan nuansa kebatian yang sama, terbitnya Keppres tersebut sebagai penambah energi bagi pemerintah Indonesia, pelaku usaha, serta semua pihak untuk melakukan reorientasi pengelolaan sumberdaya kelautan dan perikanan yang berkelanjutan sebagai salah satu upaya Volume 11 Nomor 1 April 2017 penyediaan stock ikan bagi pemenuhan kebutuhan bahan pangan serta kesejahteraan bagi masyarakat. Diharapkan kondisi ini menjadi suatu dorongan agar masyarakat Indonesia dapat mengkonsumsi ikan sebagai gaya hidup sehat sehingga kesehatan dan kecerdasan bagi bangsa Indonesia dapat terwujud. Penguatan dukungan pemerintah Indonesia terhadap pola konsumsi ikan diwujudkan dengan terbitnya Instruksi Presiden Nomor 1 tahun 2017 tentang Gerakan Masyarakat Hidup Sehat. Pada Inpres tersebut mengamanatkan kepada Menteri Kelautan dan Perikanan untuk 1) meningkatkan dan juga memperluas pelaksanaan Gerakan Memasyarakatkan Makan Ikan atau GEMARIKAN pada masyarakat; dan 2) mengawasi mutu dan keamanan hasil perikanan.

\section{REKOMENDASI}

Dari penelusuran studi pustaka serta memperhatikan kondsi di lapangan, diperlukan beberapa langkah untuk meningkatkan tingkat konsumsi ikan masyarakat Indonesia, diantaranya :

1. Dari sisi supply, beberapa hal perlu diperhatikan, diantaranya a) meningkatkan produksi ikan baik melalui usaha perikanan budidaya maupun usaha penangkapan, b) memberikan iklim kondusif untuk 
para pihak yang memproduksi ikan, c) memperlancar akses masyarakat terhadap sumbersumber ikan, d) menyediakan ikan dengan harga terjangkau, dengan memperhatikan keamanan pangan

2. Dari sisi demand, beberapa hal perlu diperhatikan, diantaranya a) perlu dilakukan tahap edukasi terhadap masyarakat tentang kemanfaatan dan implikasi dalam mengkonsumsi ikan melalui berbagai macam media, b) memasyarakatkan pilihan teknik preparasi dan pengolahan ikan yang tidak merusak kandungan gizi, c) membudayakan kuliner asal ikan di tempat yang strategis untuk berbagai kalangan masyarakat/tingkat sosial, d) memberdayakan kaum ibu untuk lebih mampu sadar mengatur pola makan keluarga dengan aneka ragam menu serba ikan, e) meningkatkan kordinasi antar stakeholder terkait untuk melaksanakan pengawasan mutu serta keamanan pangan (food safety) hasil perikanan .

\section{DAFTAR PUSTAKA}

Anonim, 2013. m.inilah.com/news /detail/ 2013. Apa sebab ikan lebih baik dari daging atau ayam?. 30 agustus 2013, diakses 21 Juni 2016 Anonim, 2014 www.wpi.kkp.go.id. Tingkat konsumsi ikan: Peluang, hambatan dan strategi. Diakses 12 Mei 2016.

Anonim, 2016. Kkp.go.id/index.php/.... Konsumsi ikan naik dalam 5 tahun terakhir. 23 Maret 2016, diakses 20 juni 2016.

Anonim, 2017. Kinerja 2016 \& Outlook 2017 Ditjen PDS, KKP.

Chotimah Kh. 2003. Analisis perbandingan jumlah konsumsi ikan pada penduduk di daerah sentra produksi dan daerah non sentra produksi di Kabupaten Pasuruan Jawa Timur serta faktorfaktor penentu jumlah kon sum sinya. Jurnal penelitian Perikanan Universitas Brawijaya. Fakultas Perikanan.Isjd.pdii.lii.go,id/i n dex.

Heruwati, E.S. 2002. Pengolahan ikan secara tradisional: Prospek dan peluang pengembangan. Jurnal Litbang Pertanian, 21 (3): 92-99

Ilham, Ny. Sri, H., dan I Ketut, K. 2002. Pendugaan parameter dan elastisitas penawaran dan permintaanbeberapa jenis daging di Indonesia, Jurnal Agroekonomi, Vol. 20, No. 2 . www.ejournal.litbang.pl.

Inpres No. 1, tahun 2017 tentang Gerakan Masyarakat Hidup Sehat.

Indrawasih R. 2016. Pola konsumsi ikan oleh masyarakat di Desa Hitumesing, kabupaten Maluku Tengah. Jurnal Masyarakat dan Budaya. Jmb-lipi.or.id/index.php. jmb

Indriana S dan Widayanti. 2006. Hubungan pendapatan, penget ahuan gizi ibu dengan ketersediaan ikan tingkat rumah tangga daerah perkotaan. Jurnal Gizi Indones iae jou rnal. undip.ac .id/index. $\mathrm{Ph}$ pjurnal gizi indonesia.

Kinasih H.R. 2012. Makan ikan dan ketahanan pangan. m.kompasiana 
07 Oktober 2012.diunduh kamis 17 Mei 2017.

Kromhout, D., Bosschieter, E.B., de Lezenne Coulanderr, C., 1985. The inverse relation between fish consumption and 20-year mortality from coronary disease. N.EnglJ.Med. 1985; 312: $1205-$ 1209.

Leaf, A. and Weber, P.C., 1988. Cardiovascular effects of n-3 fatty acids. N. Engl J Med 1988; 318: 549-557.

Oomen, C.M., Feskens, E.J.M., Rasanen, L., Fidanza, F., Nissinen, A.M., Menotti, A., Kok, F.J., and Kromhout, D. 2000. Fish Consumption and Coronary Heart Disease Mortality in Finland, Italy and the Netherlands. American Journal of Epidemiology. Vol. 151, N0. 10. USA.

Rafikasari,D.2015. Lifestyle.sindonews. com. Konsumsi ikan di Indonesai masih rendah. 20 Agustus 2015, diakses 13 Mei 2016.

Rahayu, W.P., Slamet, M., Suliantari, dan Srikandi, F. 1992. TEKN OLOGI FERMENTASI PRODUK PERIKANAN Departemen Pendidikan dan Kebudayaan, Direktorat Jenderal Pendidikan Tinggi, Pusat Antar Universitas Pangan dan Gizi, Institut Pertanian Bogor. 140 halaman.

Rahfiludin, M.Z., Cahya, T.P., Tinuk dan Istiarti. 2004. Pengaruh pelatihan makan ikan terhadp peningkatan pengetahuan, sikap, praktik dan asupan gizi ibu dan anak balita. Jurnal Kesehatan Masyarakat Indonesia , Vol. 1 No 2, 2004. P2t.uninus.ac,id.

Saefudin, D. 2015. Esensi hari ikan nasional. www.radarcirebon. com.
21 Nopember 2015, diunduh 12 Mei 2016.

Setyorini, E. Pangan Laut Belajar dari Jepang, 28 Desember 2007.Inovasi, vol 6/xviii/maret 2006.http://io.ppi-

Jepang.org/article.php.kamis 18 Mei 2017.

Sokib, N., Nurheni, Sri, P., Budi S. 2012. Strategi peningkatan konsumsi ikan di kota Depok. Jurnal Manajemen Pengembangan Industri Kecil Menengah (Ilkom.journL.IPB.AC. ID. Vol.7, No 2.

Suryawanti, S.H., Subhechanis, S., dan Hetria, M.P. 2016. Analisis Preferensi Konsumsi IKan menghadapi Natal 2015 dan Tahun Baru 2016. J. Kebij. Sosek KP. Vol. 6 (1): 15-24.

Suryadiana E., Kusharto, Clara M. N, dan Naufal M. 2014. Kontribusi konsumsi ikan terhadap tkt kecukupan protein pada suku Sunda dan Bugis disekitar Waduk Cirata, Kab. Cianjur. Diunduh 20 Mei $2017 . \quad$ http://

Repository.ipb.ac.id /handle/12345679/73456

Undang-Undang Nomor 31 tahun 2014 tentang Perikanan jo UndangUndang Nomor 45 tahun 2009

Undang-Undang Nomor 18 tahun 2012 tentang Pangan

Zulaikah,S., Laksmi W, 2004. Hubungan kecukupan asam eikosapentanoat (EPA), asam Dokosa heksanoat (DHA) ikan dan status gizi dengan prestasi belajar siswa. E.Journal. undip.ac.id/index.php/jgi. Jurnal Gizi Indonesia, Undip, Semarang. 